\title{
Buddhist-Christian Interreligious Dialogue for Spiritual Care for Transgender Hospital Patients
}

\begin{abstract}
The Pastoral Care profession in public hospitals in the United States has been largely populated and led by Protestant Christians. Buddhist practitioners have entered the field creating opportunities for Christian-Buddhist dialogue. Transgender US citizens are especially vulnerable to medical, social, and spiritual neglect in health care settings due to policy changes in the Department of Health and Human Services. Christians are also vulnerable to the manipulation of basic Christian principles by Trump and Pence. Buddhist-Christian dialogue can strengthen compassionate care and promote public practical theology for transgender hospital patients.
\end{abstract}

Keywords Buddhist $\bullet$ Christian $\bullet$ Transgender $\bullet$ Interreligious Dialogue • Law

\section{INTRODUCTION}

First they came for the socialists, and I did not speak out-

Because I was not a socialist.

Then they came for the trade unionists, and I did not speak out-

Because I was not a trade unionist.

Then they came for the Jews, and I did not speak out-

(C) The Author(s) 2020

P. A. Yetunde, Buddhist-Christian Dialogue, U.S. Law, and

Womanist Theology for Transgender Spiritual Care, https://doi.org/10.1007/978-3-030-42560-9_1 
Because I was not a Jew.

Then they came for me-and there was no one left to speak for me.

Lutheran pastor Martin Niemoller

Prescript. Years before I began writing this book, I anticipated President Trump would be impeached. He was impeached on December 18, 2019. COVID-19 was reported to the World Health Organization in late December of that year. Trump was acquitted on February 5, 2020, as the COVID-19 pandemic continued ravaging humanity. Before attention was paid to Trump's dealings with Ukraine, and before COVID-19 reared its ugly head, our government targeted transgender people in nearly every facet and sector of American life. At the time of writing, COVID-19 is demanding something different from us-a political system that is transparent, responsive to public health concerns, economically nimble, and ceases the targeting of politically-vulnerable citizens. At this time, governments across the globe are aware of the desperate necessity of garnering nearly every possible resource to protect humanity from the scourge of the coronavirus. No country will "go it alone" and thrive. Communicable diseases remind us that we are all in this together, and spiritual care providers must attend to political situations outside our clinical contexts. What happens outside impacts what happens inside. Medical professionals (many of whom are wearing garbage bags for protective gear) are putting their lives as risk, and some are dying. This is a tragedy and travesty. Impeachment reminds us that the President is accountable to the US Constitution and Trump's acquittal reminds us that in this Administration, foreign nationals are invited to meddle in our electoral processes without real consequence. Moreover, I hope these situations remind us, intergenerationally, that our survival as a species depends on recognizing and honoring our interdependence across gender, gender expression, sex, sexuality, sexual expressions, and all forms of human expression. This is what the Parable of the Good Samaritan or the Parable of Our Collective Survival, teaches us. Are we ready to learn?

Chaplains. We love chaplains who nonjudgmentally support us in times of need, often in places we don't wish to be, or places we have a difficult time adjusting to. They represent the kinds of people Jesus talked about in The Parable of the Good Samaritan. Millions of Americans receive their primary spiritual care from "good Samaritan" chaplains, ${ }^{1}$ but chaplains are not known for collectively speaking out on behalf of the oppressed. I argue that pastoral and spiritual caregivers need to be involved in democratic 
institutions beyond voting; as educated, critically thinking spiritual leaders they hold the potential to wisely engage in the democratic process in ways that can contribute wisdom and compassion in the protection of minority rights while respecting religious freedom. Unfortunately, many spiritual care professionals are not prepared for such critical involvement because seminary education and Clinical Pastoral Education (CPE) are typically not infused with legal education. How might chaplains, spiritual caregivers, pastoral counselors, and chaplain educators with some education in US religious freedom law read Christian scriptures differently? More importantly, how might these spiritual caregivers and educators act differently?

Lawyers. We love lawyers when they successfully defend our rights; we hate them when they successfully defend the rights of someone suing or prosecuting us. Human rights lawyers are known for speaking out on behalf of the oppressed, but are not known for collectively offering spiritual care to those who are sick. Though this book is not written for lawyers, how might lawyers interpret laws differently, as the lawyer learned to do in his encounter with Jesus, if those interpretations were made with the sensibility of a spiritual caregiver?

Sagacious mystics. Everyone loves the wise person who sees us for who we truly are, without judgment, and who takes the time to direct our attention toward what is good. These people may irritate us when they puncture our egos, reminding us that we are not as great as we might imagine, and when they point out unseen forces in the universe greater than ourselves. They help us see beyond the mundane and they illuminate the sublime. Sagacious mystics, unlike chaplains and lawyers, tend to transcend professional categorization and do not separate their wisdom from their identities and their behavior. Scripture, law, and being are one.

So, what happens when the incisive lawyer confronts the mystical sage with questions about the rule of law and salvation, and the sage replies that caring for others is the path? This kind of confrontation unfolds in one of the most powerfully humanizing stories of all time: The Parable of the Good Samaritan (The Parable); but The Parable is under attack in the United States, especially with respect to transgender people. Why is it that a powerfully humanizing narrative would be intentionally threatened?

In the Christian Bible, in the Gospel of Luke, a lawyer asks Jesus what he must do in order to live forever. Jesus asks him how he interprets the law. The lawyer understands the law in this way: One must love God with 
every fiber of one's being and love one's neighbor as one loves oneself. Jesus affirms the lawyer's understanding. Digging deeper, as good lawyers tend to do, the lawyer asks for Jesus's definition of the word "neighbor." Jesus tells the lawyer a story, a parable, about a man who is severely beaten and left for dead, even by religious leaders who see the dying man and cross to the other side of the road. A Samaritan, someone not esteemed in any religious or ethnic way, a commoner, perhaps even someone oppressed, gives the dying man aid and takes him to an inn for care. He pays the innkeeper, offering to pay even more than requested. The innkeeper takes the man into his care. After Jesus tells the story, he turns the question back on the lawyer, asking for his definition of the word "neighbor." The lawyer responds by equating the word neighbor with the Samaritan-a neighbor is one who shows mercy, as the Samaritan showed mercy upon the dying man. Jesus affirms the answer and instructs the lawyer to do likewise. ${ }^{2}$ We do not know the end of the story; we don't discover how the lawyer enacts or does not enact Jesus's instruction. We do, however, know the story of a challenge to Jesus's message, a challenge that is taking place in contemporary America. The Trump-Pence administration, in the name of Christianity, is currently flouting the Good Samaritan ethos. Why?

Prior to the 2016 presidential election in the United States, real-estate mogul and presidential candidate Donald J. Trump, with celebrity status and wealth but without a strong political base, struck a deal with some politicized and energized Christian evangelicals. These evangelicals sought political access and power they certainly would not have found with Trump's opponent, liberal Protestant, feminist Hillary Rodham Clinton, a former first lady, US Senator, and secretary of state. Though candidate Trump did not espouse discrimination against transgender citizens in the presidential debates, the base brought their anti-LGBTQ and especially their anti-transgender agenda to his presidency. With the help of Russian meddling in social media and voting systems, Trump, despite his nonChristian lifestyle, became the darling of some Christian evangelicals, not to mention some African-American Christian pastors and many white nationalists, some of whom were and are in the Trump-Pence administration. Politics makes for strange bedfellows.

Trump entered the presidency on January 20, 2017. Just shy of a month in office, his administration eliminated federal protections that allowed transgender students to use bathrooms consistent with their gender identity. ${ }^{3}$ About one year later, President Trump said on Religious Freedom Day, 
Our Constitution and laws guarantee Americans the right not just to believe as they see fit, but to freely exercise their religion. ... No American-whether a nun, nurse, baker, or business owner-should be forced to choose between the tenets of faith or adherence to the law. ${ }^{4}$

A Christian nun would not struggle between the tenets of her faith and The Parable, because The Parable is a part of her faith. A nurse would not struggle between The Parable and their profession, because The Parable is part of their profession. Through the equal protection clause of the Fourteenth Amendment, this country seeks to ensure that all citizens are treated as endowed with the same substance, thereby recognizing that no one is better than or more entitled to rights than anyone else. Under the Fourteenth Amendment, bakers and other business owners offering their services and products to the public may not deny their services and products to different classes of people; but that is indeed happening, and it is happening legally. The Parable is under attack in the name of religious freedom, but the Good Samaritans in our midst can use the power of the principle to re-imagine The Parable beyond its focus on the goodness of one human toward another human. I will return to the process of this re-imaging in Chap. 6.

The Parable is being twisted, civility is being undermined, and compassion is being devalued. As the gender-bending rock star David Bowie sang in lamentation about political corruption,

This is not America ... A little piece of you

The little peace in me

Will die

For this is not America ${ }^{5}$

The small pieces of peace within our hearts that have been cultivated by The Parable are dying as transgender US citizens are being sacrificed on the political altar. All the while, The Parable teaches us not to make others vulnerable and not to exacerbate the vulnerability of those who are struggling to survive.

As I watched the 2016 presidential debates, when candidate Trump initially had no discernable political base, I saw from the outside the development of his relationship with former Indiana Governor Mike Pence and Pence-style Christians. In short, Pence-style Christians believe in a Christianity that is more biblically literal, believe God is judgmental 
and damning, and believe in separating "sinners" from the "saved." They do not believe in the separation of church and state; arguably, they believe in church as state. The failed attempt to adopt a radically discriminatory Religious Freedom Restoration Act (discussed in more detail in Chap. 4) in Indiana demonstrates this assertion. How can the twisting and destruction of The Parable occur in a country where many hospitals throughout the country are named "Good Samaritan" and where we continue to celebrate Good Samaritan acts in the news? This is not America. Or, is it?

Our organizing principles of compassion and mercy are obviously fragile. For as we have seen in a short period of time, the very possibility of human flourishing among millions of Americans can be undermined by religious prejudices, laws, and policies that change with radical changes in the political situation.

The US transgender community is under attack in nearly every sector of society by its own federal government, nominally in the interest of protecting the religious freedom of anti-trans people to discriminate. My theological formation in womanist practical theology informs my ethic of creating safe spaces for everyone, including transgender people. This womanist safe-space sensitivity helps me see that the US public health care system is being impoverished through the Conscience and Religious Freedom Division (CRFD) of the Department of Health and Human Services - in the interest of protecting the religious freedom to discriminate. African-American theologically educated political scientist, author, television host, and advocate Melissa Harris-Perry's work inspires me to say something, write something, and do something about the religionfueled human rights situation before us because transgender people are under siege in the Trump-Pence administration. Harris-Perry, though not considered by many to be a theologian per se, advocates in a theologically sophisticated, compelling, and multi-faceted manner for sexualityoppressed people. She is an inspiration for chaplains and spiritual care professionals seeking to take their ministries of compassion to the streets, within the academy, and throughout the airwaves. As a political scientist, she is also an exemplar for public practical theological leadership. Leadership matters. Where transgender rights were emerging in schools, public restrooms, the military, and in health care under the Obama Administration, the Trump-Pence administration in short order repealed and attempted to repeal regulations that supported trans people in schools, employment, housing, health care, and the military. 
According to The National Center for Transgender Equality, these are some actions, in various sectors of society, that have been taken against transgender citizens:

March 2017: The Department of Housing and Urban Development (HUD) removed links to four key resource documents from its website, which informed emergency shelters on best practices for serving transgender people facing homelessness and complying with HUD regulations.

March 28, 2017: The Census Bureau retracted a proposal to collect demographic information on LGBT people in the 2020 Census.

March 31, 2017: The Justice Department announced it would review (and likely seek to scale back) numerous civil rights settlement agreements with police departments. These settlements were put in places where police departments were determined to be engaging in discriminatory and abusive policing, including racial and other profiling. Many of these agreements include critical protections for LGBT people.

April 4, 2017: The Justice and Labor Departments cancelled quarterly conference calls with LGBT organizations; on these calls, which have happened for years, government attorneys share information on employment laws and cases.

October 5, 2017: The Justice Department released a memo instructing Department of Justice attorneys to take the legal position that federal law does not protect transgender workers from discrimination.

October 6, 2017: The Justice Department released a sweeping "license to discriminate," allowing federal agencies, government contractors, government grantees, and even private businesses to engage in illegal discrimination, as long as they can cite religious reasons for doing so.

December 14, 2017: Staff at the Centers for Disease Control and Prevention were instructed not to use the words "transgender," "vulnerable," "entitlement," "diversity," "fetus," "evidence-based," and "science-based" in official documents.

January 18, 2018: The Department of Health and Human Services Office for Civil Rights opened a "Conscience and Religious Freedom Division" that will promote discrimination by health care providers who can cite religious or moral reasons for denying care. (I return to this subject in Chap. 4.)

January 26, 2018: The Department of Health and Human Services proposed a rule that encourages religious refusals in health care targeting trans people, people who need reproductive care, and others.

February 18, 2018: The Department of Education announced it will summarily dismiss complaints from transgender students involving exclusion from school facilities and other claims based solely on gender identity discrimination. 
March 23, 2018: The Trump administration announced an implementation plan for its discriminatory ban on transgender military service members.

May 11, 2018: The Bureau of Prisons in the Department of Justice adopted an illegal policy of almost entirely housing transgender people in federal prison facilities that match their sex assigned at birth, rolling back existing protections.

August 10, 2018: The Department of Labor released a new directive for Office of Federal Contract Compliance Programs (OFCCP) staff, encouraging them to grant broad religious exemptions to federal contractors with religious-based objections to complying with nondiscrimination laws. It also deleted material from an OFCCP frequently asked questions on LGBT nondiscrimination protections that had previously clarified the limited scope of allowable religious exemptions. ${ }^{6}$

Since this list was compiled, in October 2018, it was leaked to the press that the Trump-Pence administration would strike the category of transgender people from Title IX legislation. ${ }^{7}$ In January 2019, the Trump-Pence administration won a federal court legal victory against trans people with a gender dysphoria diagnosis, barring them from military service. $^{8}$

If the Parable of the Good Samaritan is part of Christian teachings and part of our national values, then these Christians are actively paving the path to hell by making health care clinics, hospice organizations, hospitals, and so on, places where transgender people (and others) can be refused care, even by spiritual care and medical professionals, on religious grounds. These governmental-based discriminatory policies extend beyond health care to various sectors of society. Is this a perversion of Christianity? Why should I, a cisgender person, care?

The first transgender person I met was my mother's colleague, a federal employee, who was transitioning from male to female in Indianapolis in the early 1980s. My mother explained that even though neither of us understood what "Tom" was going through, I should still respect her. My mother had demonstrated throughout her life that being a good friend to all enriches life. Since meeting Tom, I have come into contact with many people who experience gender in a variety of ways. In the early 1990s, a prospective financial planning client of mine transitioned from being a woman to being a man. One of my first pastoral counseling clients was a trans woman. A friend with whom I completed Buddhist leadership training identifies as genderqueer. I served on a panel with someone who 
was gender nonconforming and is now a man. I worked with a mental health care intern who had transitioned from woman to man. One morning while walking into the front door of the seminary where I teach, I met a lesbian couple that had been evicted from a Christian shelter for homeless people because one of the women was trans and wanted to use the women's restroom. I have provided pastoral counseling to clients who have transitioned from one gender to another, and now I have an esteemed seminary professor colleague with whom I have a collaborative relationship.

I have learned, since the mid-1980s, in different contexts and in different parts of the country, that no matter one's gender assignment at birth, gender alone does not define a person; a change in gender does not negate an individual's personhood.

I am not an expert on what it means to be a transgender person, nor am I an expert in transgender spiritual care. My trans and religious conversation partners, Aurora Jade Pichette (www.jadepichette.com), and Jake Bradley and Nate Metrick of Elements Consulting (www.elementsconsulting.org), are the experts. My expertise, as a law-educated, womanistinspired practical theologian educated in spiritually integrated Marriage and Family Therapy, is in seeing how religious freedom laws are intentionally distorted to negatively impact transgender people while they are seeking health care. This book is offered as a resource for inspiring chaplains and spiritual caregivers in hospitals to widen the field of spiritual care for trans hospital patients by undergoing our own transitioning: away from leaving religious freedom law literacy in the hands of lawyers exclusively; away from religious monologue and toward interreligious dialogue; and away from exclusivist private, patient-centered care toward public, hospitalcommunal care. Changes in the White House demand that we increase our vigilance toward the care of others by speaking publicly about oppression.

My mother raised me to care about the well-being of people, the planet, and the universe and its inhabitants. We share a cosmic home with countless species. I am not a transgender person, but I believe that if I were, my fundamental desires would remain the same: love, respect, safety, compassion, empathy, work, fun, housing, an education, freedom, faith, family, and health care. I do not locate myself entirely within Christian devotion and worship. I define myself as an interfaith Buddhist practitioner. I was raised in the United Methodist Church, worked abroad and stateside as a Church of the Brethren volunteer, attended a silent Quaker Meeting for some years, attended an Episcopal Church for some years, and a Lutheran Adult Sunday School. I was introduced to Buddhism through 
Thich Nhat Hanh's writings, the Zen Hospice Project where I volunteered, the Community of Mindful Living sanghas in the San Francisco East Bay, and Spirit Rock Meditation Center. I still embrace the Jesus-Christian ethos in which I was reared. I eventually entered and withdrew from leadership training in the Community of Mindful Living and entered and completed leadership training in Spirit Rock's Community Dharma Leaders program. I earned a master's degree at a Catholic University and a doctor of theology degree from a Presbyterian seminary. I have a law degree from a state university.

Through my travels through religious and spiritual traditions and communities, I have come to love a broad range of scriptures that arise out of various traditions, from The Gospels to The Way of the Bodhisattva to the Daode jing to the Bhagavad Gita. I see myself as a witness to the suffering we inflict upon one another. I am convinced that through spiritual practice, we can learn to treat one another better than we do.

Christianity teaches me about loving my neighbor as I love myself. Buddhism teaches me how to understand suffering, my own and another's, without sliding into despair, with a willingness and capacity to be present and appropriate. Christianity teaches me to be an advocate and Buddhism teaches me to take care of myself as I advocate for others. Neither tradition helps me to understand trans people specifically (though there are teachings that are helpful), and neither tradition has fully prepared me for examining what it will take for health care organizations in an increasingly fascist-leaning Executive Office (the abuse of our democratic institutions by neglect, the demonization and of the press and vilification of journalists, autocracy, the emboldening of hate groups, and the intimidation of resistance movements), to intentionally become hospitable toward transgender people. Supported by Christianity and Buddhism, I wish to forge a new path toward understanding and welcoming all people who are vulnerable in this particularly destructive political moment in the United States.

Being hospitable is a value shared by all major religious traditions, including Buddhism, Christianity, Hinduism, Islam, and Judaism; being hospitable, or having the ability to be a host, is the very action out of which hospitals and hospices were originally founded. The word "hospital" is derived from "ospital," meaning, "hostel, shelter, lodging." Indeed, churches and religious organizations were the first creators of hospitals, which were primarily intended for serving poor people. ${ }^{10}$ 
Chaplains serve as hosts in hospitals and hospices; they provide hospitality in the form of religious and spiritual support, when requested. In $A$ Ministry of Presence: Chaplaincy, Spiritual Care, and the Law, Winnifred Fallers Sullivan offers that chaplains are "trained by religious communities [to] minister to a clientele often unmarked at that moment by any specific religious identity, and they do so on behalf of a secular institution bound, at least theoretically, to rational epistemologies... The chaplain has, without paradox, become a priest of the secular ... attempt[ing] to integrate universalist and particularist understandings of the flourishing of human beings under the banner of religious freedom." 11

Sullivan also claims, "The new 'clinical' chaplaincy has a different role and a different purpose. The chaplain has now become a member of the medical team." 12 Consequently, as a member of the medical team, utilizing a ministry of presence,

Each [chaplain] experiences the intimate and immediate face of death and dying and the insistent presence of difficult moral decisions. But they share much with other forms of chaplaincy today. The diversity of their clientele, the ambiguity of lines of authority, the transience of the encounter, and, above all, the pressure to work in a radically undefined setting religiously speaking, and a rapidly deconstructing religious field-while justifying that work using the seductively scientistic language of spiritual assessment and care-characterizes the work that chaplains do in every place. Chaplains are at a particularly interesting and focused interface between church, state, society, and a rapidly changing religious terrain. ${ }^{13}$

Due to the fact that chaplains are educated in, exposed to, and trained in a variety of disciplines, including theology and critical analysis of sacred texts, professional chaplains know that interpreting The Parable against vulnerable patients is a gross perversion. The US Department of Health and Human Services (HHS) created an Office for Civil Rights (OCR) enforcement mechanism called the Conscience and Religious Freedom Division (CRFD) to enable health care employees to file complaints online if they cannot remove themselves from caring for people they do not like, in the name of religion. It is estimated that this initiative will cost hundreds of millions of dollars every year. It is estimated that the cost to implement CRFD is $\$ 900,000$, that it will cost $\$ 312.3$ million this year, and $\$ 125.5$ million every year. Are our health care systems able to survive such financial losses? ${ }^{14}$ The Trump-Pence administration is also promoting vigilante 
justice by inviting people to file complaints on another's behalf without their knowledge or permission. Can you image, for example, a member of a religion that despises white people removing herself from caring for all white patients in a hospital? Should she be entitled to keep her job? Can you imagine a white hospice worker belonging to a religion that espouses white supremacy removing himself from the care of all people of color? Can you imagine a Jewish health care clinic employee who believes that neo-Nazis should not be provided treatment because they advocate violence having the right to refuse to provide care? Should a Roman Catholic priest who is a chaplain be able to exercise his religious freedom by performing an exorcism on anyone he deems in need? Whether it is the individual hospital, hospice, or clinic employee with their particular belief systems encountering individual patients who fall outside the net of love and compassion of their religious, spiritual, and ethical systems, should the entire hospital, hospice, or clinic be denied federal funding based on those religious differences?

Should the United States, with a Constitutional mandate in the First Amendment to keep church and state separate, be involved in withholding necessary funds for sites of hospitality, based on religious disputes within those organizations? It is important to note here that though the founding fathers were stricter regarding the separation of church and state, over time, and especially recently, the US Supreme Court has been more liberal on questions of religion-state relationships. Sullivan says,

Decisions of the U.S. Supreme Court in the last couple of decades have shifted the Court's interpretation of the religion clauses of the First Amendment away from the high separationism of the middle part of the twentieth century toward a jurisprudence that increasingly sees religion as being neither particularly threatening nor particularly in need of protection. ${ }^{15}$

Is this neutral attitude shifting more toward protection? As it relates to the executive branch, there is a clear shift toward protection through the Trump-Pence administration's Conscience and Religious Freedom Division.

As a practical theologian, one who has worked in hospice, hospital, and mental health care settings, I want to know how to remedy the things that have become so wrong, especially for transgender people. In the Gospel of Matthew, Jesus says, "Truly I tell you, whatever you did for one of the least of these [italics mine] brothers and sisters of mine, you did for me." Biblical 
literalists, ready for a self-righteous argument, may pounce on Jesus's words, saying, "See, it says 'brothers and sisters,' not transgender people." Who could disagree? The incisive lawyer in The Parable, who questions Jesus about the definition of the word "neighbor," might ask, "What is a brother? What is a sister? What do we call people who don't identify as either? If I do for the least of these, those who are neither, am I also doing for Jesus?" When taking scripture literally, we become spiritually stuck in bibliolatry-making the Bible an idol of worship. The lawyer questioning Jesus and Jesus sharing The Parable serves as an interrelational dynamic for avoiding bibliolatry; the lawyer, who was capable of reading and understanding the law as it was written, was yet in need of guidance from a wise mystic.

Wise mysticism helps us see what is not obvious to the naked eye. Wise mysticism helps us understand our place in the cosmos, levels our egos, and transforms negative perceptions, enabling us to see beyond delusions, delusions that include how we may view trans people, whether they are represented in our sacred texts or not. The wise mystic in us might answer the incisive lawyer in us by saying, "The least of us is never determined based upon gender identification only, but on vulnerability and need, and we are always subject to vulnerability and need." A common person of no religious title or position, perhaps no religious belief and certainly vulnerable and in need, can still do for the least of these. How might we go forth and do so without explicit guidance from our ancient scriptures?

Being transgender, as we understand it today, rests outside many ancient sacred texts. For Bible literalists, there is no mention of what we should do for Jesus if we encounter someone who was a brother but is now a sister, was a sister but is now a brother, or someone who is not a sister or a brother, yet is still a person. Yet, reading the Gospels in their entirety, it is reasonable to imagine that anyone who is "the least of these" and is given aide by another will share some of the spiritual substance of Jesus's substance-an enlightening spirituality. This enlightening spirituality is what I call The Christ and from a Buddhist perspective, The Tathagata (subjects I discuss in Chaps. I and 3). I am suggesting that the concept of The Christ and the concept of The Tathagata overlap and provide an interreligious bridge of understanding, compassion, and action for the benefit of the clinical spiritual care of transgender people now under attack through the auspices of the Department of Health and Human Services' Conscience and Religious Freedom Division. 
Transgender people are targeted by the federal government from a multitude of directions, in all places, regardless of age and ability, in society at large, in family at small, and oftentimes intrapsychically due to multidimensional societal invalidation. No ancient religious text directly and explicitly prepares us for deeming transgender people fully human and worthy of respect in the material world if we already have a notion that aligning one's body with one's persistent thoughts about oneself is wrong. How many people have dyed their hair in an effort to look younger when in the material world, we do not actually get younger? How many people have had plastic surgery in an effort to maintain a youthful appearance when we do not "age in place?" How many women have had medical procedures in order to have children? How many men take erectile dysfunction medication past their sexual prime? Trans people are not the only people who take measures to align their bodies with their selfconcepts, and that is important to note as we move toward the recognition that we share the desire to feel and be whole and not be discriminated against just because we are making these decisions. It is the recognition that we human beings desire to feel and be whole that forms the ground for revitalizing and re-imagining The Parable of the Good Samaritan as The Parable for Our Collective Survival.

The revitalization and re-imagining of The Parable arguably begins with Chap. 1, "Buddhist-Christian Interreligious Dialogue for Spiritual Care for Transgender Hospital Patients," where I introduce ways for Buddhist and Christian spiritual caregivers to engage in interreligious dialogue and cooperation to expand the field and scope of care within the hospital context as well as how to enter Buddhist dialogue with Christians, especially as it relates to St. Paul's letters to the Galatians and Colossians about "identity disformation" in Jesus Christ. In Chap. 2, "Spiritual Care and Political Involvement, Womanist Public Theology and Boston Medical Center," I utilize the life and work of black feminist, womanist-influenced, African-American public intellectual Melissa Harris-Perry to illustrate how one might engage citizenship through being a scholar, a journalist, an advocate, and a theologian. In Chap. 2, I also examine and analyze the data from three surveys - one with chaplains, one with pastoral counselors, and the other with chaplain educators - all related to religious freedom issues, spiritual care, and education. I conducted these surveys to arrive at a sense of what some chaplains, pastoral counselors, and chaplain educators really think about religious freedom law and determine if CPE programs incorporate religious freedom law literacy in their curricula. In addition to 
the surveys, I include a brief case study on the Clinical Pastoral Education program at Boston Medical Center's Center for Transgender Medicine and Surgery. In Chap. 3, "Thich Nhat Hanh, the Avatamsaka Sutra, and Lady Mahamaya," I introduce Vietnamese Zen Buddhist monk Thich Nhat Hanh's teachings on the Avatamsaka Sutra and, more specifically, on Lady Mahamaya, the Buddha's mother. Hanh's cosmic Zen Buddhism promotes the notions of emptiness, impermanence, and interdependency, even as it relates to gender. Nhat Hanh's cosmic Buddhology offers "intelligent design" Christians engaged in interreligious dialogue with Buddhists, mystical wisdom and spiritual practices to consider when contemplating deepening empathy with transgender hospital patients. In Chap. 4, "Think Like a Lawyer, Act Like a Chaplain," I examine issues related to the US Constitution, case law, and state legislation related to religious freedom and spiritual care. In Chap. 5, "A New 'Shock Method' for Creating a Compassionate Health Care Team," I introduce a combination of methods for widening the field and scope of spiritual care for trans hospital patients through the writings of black, Buddhist, queer activists Rev. angel Kyodo williams, Lama Rod Owens, Professor Jasmine Syedullah, and Christian pastoral theologian Brita Gill-Austern. In Chap. 6, "Conclusions and Recommendations," I offer concluding remarks, recommendations, and a vitally important reinterpretation of The Parable of the Good Samaritan for our collective survival.

All, too, will bear in mind this sacred principle, that though the will of the majority is in all cases to prevail, that will to be rightful must be reasonable; that the minority possess their equal rights, which equal law must protect, and to violate would be oppression.

Thomas Jefferson

Most Christian 'believers' tend to echo the cultural prejudices and worldviews of the dominant group in their country, with only a minority revealing any real transformation of attitudes or consciousness. It has been true of slavery and racism, classism and consumerism and issues of immigration and health care for the poor.

Richard Rohr

One of my messages to Republicans is very simple: One-third of your schedule should be listening to people in minority communities.

Newt Gingrich ${ }^{16}$ 
Philosopher Craig Calhoun says,

Religion is threatening, inspiring, consoling, provocative, a matter of reassuring routine or calls to put one's life on the line. It is a way to make peace and a reason to make war. As the great Iranian sociologist and Islamic reformer Ali Sharyati put it: "Religion is an amazing phenomenon that plays contradictory roles in people's lives. It can destroy or revitalize, put to sleep or awaken, enslave or emancipate, teach docility or teach revolt." No wonder debates about religion in the public sphere can be so confusing. ${ }^{17}$

The multiple and conflicting potentialities and impacts of religion in the US's pluralistic and democratic society necessitates chaplains and spiritual caregivers being deeply engaged in interreligious dialogue and public advocacy for the oppressed in order for us to survive as whole beings in a whole nation, contributing to a whole continent and world. When I think about interreligious dialogue, I imagine two parties from different religious traditions engaged with each other on matters vital to their religious belief systems, with the knowledge that the other possesses different beliefs, with a desire to know the other more deeply in order to cohabitate more peaceably. Judith Butler writes about cohabitation, specifically in the Israel-Palestine context:

Cohabitation forms the ethical basis for a public critique of those forms of state violence that seek to produce and maintain the Jewish character of the state through the radical disenfranchisement and decimation of its minority, through occupation, assault, or legal restriction. These are attacks on a subjugated minority, but they are also attacks on the value of cohabitation. ${ }^{18}$

The Trump-Pence administration's systematic attack on transgender people is an attack on cohabitation - by the power of religious freedom, we have been given a "license to prey" on transgender citizens through discrimination in housing, the workplace, education, the military, and elsewhere. Butler's cohabitation concept is complex and beyond the oncepopular question, “Can't we all just get along?" posed by Rodney King, an African-American man who was brutally beaten by police in 1991 . Butler is talking about the fact that we cannot choose who inhabits this planet without committing acts of genocide. The fact that we cannot choose who inhabits the planet without committing acts of genocide informs us of a variety of moral options and ethical dilemmas before us. 
One of those moral options is respecting the fact that others value the traditions they identify with. Vietnamese Buddhist monk Thich Nhat Hanh writes,

Sharing [interreligious dialogue] in this way is important and should be encouraged. But sharing does not mean wanting others to abandon their own spiritual roots and embrace your faith. That would be cruel. People are stable and happy only when they are firmly rooted in their own tradition and culture. To uproot them would make them suffer. ${ }^{19}$

Nhat Hanh seems to support the notion of cohabitation by suggesting that people should be able to maintain the strength of their "spiritual roots" while engaging in interreligious dialogue. However, in clinical settings, we are all rooted in one vast space that houses a multitude of individuals rooted in different beliefs and traditions. How do we work within these tensions in a balanced way?

In chaplaincy training, chaplain educators instruct their students in clinical settings where they encounter patients from all walks of life, with a variety of illnesses, undergoing a variety of procedures, and encountering a variety of professionals. Chaplaincy students, if they are fortunate, enter into a clinical setting with other students from different religions and worldviews. If their fortune is extended, the other students will be from different cultures, nations, age groups, sexualities, and gender expressions. Great fortune is had if the student has a chaplain educator who embraces and even represents diversity and plurality.

In this chapter, I draw on Christian theologian Paul O. Ingram's The Process of Buddhist-Christian Dialogue, discussing ways Buddhists and Christians working together as chaplains and chaplain students in hospitals can contribute to hate-proofing their hospitals on behalf of trans patients. I will also build on Ingram's processes to offer additional perspectives on how Buddhist-Christian dialogue in the hospital context for spiritual care for trans patients might be achieved. But before engaging Ingram, it is important to note that interreligious dialogue will not occur on any deep psychologically transformative level if dialogue partners are so narcissistically impaired as to prohibit deep listening, empathy, and authentic consideration of others. Nhat Hanh says,

In true dialogue, both sides are willing to change. We have to appreciate that truth can be received from outside of - not only within-our own 
group. Dialogue is not a means for assimilation in the sense that one side expands and incorporates the other into its "self." Dialogue must be practiced on the basis of "non-self."

"Non-self" in this context is defined as not afflicted with Narcissistic Personality Disorder (NDP), which is,

A pervasive pattern of grandiosity (in fantasy or behavior), need for admiration, and lack of empathy, beginning by early adulthood and present in a variety of contexts, as indicated by five (or more) of the following:

1. Has a grandiose sense of self-importance (e.g., exaggerates achievements and talents, expects to be recognized as superior without commensurate achievements).

2. Is preoccupied with fantasies of unlimited success, power, brilliance, beauty, or ideal love.

3. Believes that he or she [or they] is "special" and unique and can only be understood by, or should associate with, other special or high-status people (or institutions).

4. Requires excessive admiration.

5. Has a sense of entitlement (i.e., unreasonable expectations of especially favorable treatment or automatic compliance with his or her [their] expectations).

6. Is interpersonally exploitative (i.e., takes advantage of others to achieve his or her [or their] own ends).

7. Lacks empathy: is unwilling to recognize or identify with the feelings and needs of others.

8. Is often envious of others or believes that others are envious of him or her [or them].

9. Shows arrogant, haughty behaviors or attitudes. ${ }^{21}$

NPD, a Western understanding of the extreme form of Buddhist "selfing," does not allow for the cultivation of empathy and compassion necessary to allow oneself to be impacted in interreligious dialogue. Since NPD can be experienced by anyone in any religious tradition, one's personality structure should be self-assessed and assessed by the Clinical Pastoral Educators (those who hire, educate, and supervise chaplain residents and interns) interviewer(s) before committing to interreligious dialogue. Assuming there is no NPD or other personality obstructions to interreligious dialogue, there are several ways interreligious dialogue, according to Ingram, can be conducted. 
Ingram, drawing on Process Theology and the Natural Sciences, identifies four Buddhist-Christian dialogue processes, including Conceptual Dialogue, Buddhist-Christian Interior Dialogue, BuddhistChristian Socially Engaged Dialogue, and Conceptual Dialogue with the Natural Sciences. Conceptual Dialogue is when dialogue partners limit their communications to the realm of concepts, discussing whether there is a concept of heaven in Buddhism, for example, or discussing why Christians believe they can live forever, as another example. BuddhistChristian Interior Dialogue comes as the result of dialogue partners sharing their experiences of contemplation, prayer, and meditation. Buddhist-Christian Socially Engaged Dialogue has to do with matters of justice, peace making, and action. Conceptual Dialogue with the Natural Sciences is a way of knowing whether or not concepts are in accord with nature.

Understanding each process, though none of the processes are directly related to spiritual care in a hospital setting, can contribute to the formulation of a more specific process that supports the expansion of the field of compassionate spiritual care specifically for transgender people. Regarding Conceptual Dialogue, Ingram says,

The focus of Conceptual Dialogue is doctrinal, theological, and philosophical. It concerns a religious tradition's collective self-understanding and worldview. In Conceptual Dialogue, Buddhists and Christians compare theological and philosophical formulations on such questions as ultimate reality, human nature, suffering and evil, the role of Jesus in Christian faith, the role of the Buddha in Buddhist practice, and what Christians and Buddhists can conceptually learn from one another. ${ }^{22}$

It should be noted here that no matter the concepts under investigation, a Buddhist's ethical duty is to know the concept and detach from it. Nhat Hanh states,

Life is so precious, too precious to lose just because of these notions and concepts. ... Concepts like "nirvana," "Buddha," "Pure Land," "Kingdom of God," and "Jesus" are just concepts; we have to be very careful. We should not start a war and destroy people because of our concepts. ${ }^{23}$

Certain contexts can support Conceptual Dialogue, like courses and intentional dialogue groups, where time is permitted for the unfolding of 
doctrine, theology, and philosophy from at least two distinct traditions. The more diverse the traditions, the greater the chances for one to be able to articulate one's own theology and engage others with different theologies. ${ }^{24}$ Chaplains-in-training, as well as those who are already on the job, typically do not have the luxury of time. Despite the busy nature of many hospital settings, it would be wise to make time for BuddhistChristian Spiritual Care Dialogue related to transgender patients. Christian and Buddhist chaplains could begin their dialogues with religious anthropologies, asking questions like, What is a person? Can a person experience illness? Pain? Can a person experience healing? A cure? What is sex? What is gender? What about the body is "sacred," as in, not to be changed? What about a person is permanent? Is a transgender person a "person?" Is a cisgender person a "person?" In short, what about Christianity tells you this being is a person? What about Buddhism tells you this being is a person? How does this square with the Buddhist concepts of no self or nonself?

In addition to Process Theology and Natural Science, Ingram also references theologians Karth Barth, Paul Tillich, Jurgen Moltmann, Karl Rahner, John B. Cobb, Jr., John B. Keenan, Winston L. King, Hans Kung, Seiichi Yagi, Masaaki Honda, Lynn de Silva, and Bihikkhu Buddadasa regarding how to engage in Buddhist-Christian dialogue. This kind of Conceptual Dialogue is purely academic. One can fully engage in Conceptual Dialogue and not become more skilled in giving spiritual care to transgender people, so Conceptual Dialogue alone may stay in the realm of concepts.

Still, on the question of what is a person, Ingram advances the argument that the natural sciences must be brought into dialogue with religious and theological concepts because,

The natural sciences provide a continual stream of remarkable insights into the nature of physical reality across a wide range of domains. In the process, the natural sciences inspire wonder and, for most scientists and many faithful participants throughout the world's religious traditions, great reverence. ${ }^{25}$

Ingram is aware of how frightening this prospect is for some Christians, especially those who believe in the concept of "intelligent design":

Most nineteenth-century biologists accepted Darwin's theory, although some, like Louis Agassiz, challenged it by arguing that highly complex 
individual organs (like the human eye) and ecologically sensitive species (like bees and flowers) cannot evolve through the sort of minute random steps described by Darwin. To survive, Agassiz argued, each modification must be beneficial. But complex organs and organic relationships only work as a whole. They cannot develop in steps. So he proposed that complex organisms reflect intelligent design, and thus, testify to both the existence and reality of God. ${ }^{26}$

It is this concept and its impulse that contributes to physical, verbal, and emotional aggression as well as the medical neglect of some transgender patients. Intelligent Design Christian chaplains, in a trialogue with natural science and Nhat Hanh's Buddhist teachings, might ask the question, "If the transgender being is a person engaged in intentionally and actively destroying God's intelligent design, how can I be compassionate toward them?" A Buddhist chaplain might ask a Christian chaplain who is an adherent of Intelligent Design, "How can I come to understand gender as something more than a mental construct, something of real importance?" They all may ponder why both sexes have testosterone and estrogen and that hormonal levels change over time. These questions are not meant to be prescribed, but are offered as examples of how to think about natural science and religion together, while keeping in mind the fact that there is a person, or people, in our midst in need of immediate attention.

As a pastoral counselor, I would add here that all of the dialogues need to include psychology, in particular, an understanding Gender Dysphoria (GD).

Gender dysphoria involves a conflict between a person's physical or assigned gender and the gender with which he/she/they identify. People with gender dysphoria may be very uncomfortable with the gender they were assigned, sometimes described as being uncomfortable with their body (particularly developments during puberty) or being uncomfortable with the expected roles of their assigned gender.

People with gender dysphoria may often experience significant distress and/or problems functioning associated with this conflict between the way they feel and think of themselves (referred to as experienced or expressed gender) and their physical or assigned gender.

The gender conflict affects people in different ways. It can change the way a person wants to express their gender and can influence behavior, dress and self-image. Some people may cross-dress, some may want to socially transition, others may want to medically transition with sex-change surgery 
and/or hormone treatment. Socially transitioning primarily involves transitioning into the affirmed gender's pronouns and bathrooms [all italics mine]. ${ }^{27}$

In this definition are the words "may," "different ways," and "can." It is important to note that the definition of GD is fluid, yet the Trump-Pence administration's military ban on transgender recruits presumes all transgender recruits experience GD and all experience GD in the same way. Chaplains would do very well by transgender patients to avoid totalizing patients in this way.

I add the GD definition not to suggest that one has to agree with it, but to state that chaplains need to understand how psychiatrists view this phenomenon so that a chaplain's spiritual care interventions support the patient's peace of mind and peace of body while they are in the hospital for any reason.

Another Buddhist-Christian dialogue process is Buddhist-Christian Socially Engaged Dialogue. Ingram says,

Socially engaged Buddhists are uncompromising in the practice of nonviolence, and for Christians this has raised questions about justice. Justice is a central theological category in Christian social activist traditions, but the notion of justice has not played an equivalent role in Buddhism. Christian tradition gives priority to loving engagement with the world as the foundation of establishing justice. So for Christians, the question is to what extent is nonviolent compassion toward all sentient beings, even to aggressors doing harm to whole communities of persons, itself an occasion for injustice? ${ }^{28}$

Buddhist chaplains might ask, "If you say God is love, that Jesus is love, and you commit acts of violence against others, even to save others, is that justifiable?" A Christian chaplain might ask, "How is it compassionate to be a witness to someone else's harm when you could have intervened, but chose not to?" A Buddhist chaplain might ask, "Here we have a transgender patient living in a society that is dangerous. What is your role in advocating for safety for them?" The Christian chaplain might ask, "How can I advocate for those I do not love?" Again, these questions are meant to be examples, not prescriptions. Chaplains of different religions (and no religions) work together to meet the needs of those in their care. In order to offer the most appropriate care possible, they need to talk to one 
another, know one another, become conversant in other "religion languages," and be able to call on their colleagues when they think they are unable, in the moment, to serve a patient. Chaplains are expected to be empathetic, and of vital importance, be curious about another's belief system.

Buddhist-Christian Interior Dialogue is the communication that comes after participants have contemplated, meditated, or prayed for a considerable amount of time, in silence. Nhat Hanh says,

I have noticed that Christians and Buddhists who have lived deeply their contemplative lives always come to express themselves in more non-dualistic, nondogmatic ways. Christian mystics and Zen masters never sound speculative or intellectual. Their speculative minds have given way to a nondiscursive spirit. Because they have learned not to get caught in notions or representations, they do not speak as though they alone hold the truth, and they do not think that those in other traditions are going the wrong way. ${ }^{29}$

Dialogue partners share what they experience. Ingram writes,

Buddhist doctrines guide the practice of meditation in all schools of Buddhism. The purpose of Buddhist meditation is to purify the mind of mental distortions caused by clinging to permanence so that one can apprehend the "Emptiness" (sunyata) of things and events and thereby not cling to delusions, particularly the delusion of permanent selfhood. Accomplishing this requires a powerfully-concentrated mind. While there exists a plurality of meditative disciplines, five common assumptions guide Buddhist practice traditions, including

1. Since the development of mindfulness requires the avoidance of negative activities ... ethics is the foundation.

2. Meditation can be practiced by concentrating on just one object.

3. Meditation can be analytical ... through which the reasons and supporting attitudes and emotions ... can be apprehended and replaced by nonegoistic emotions.

4. Meditation may also be a reflection on the various levels of a spiritual path.

5. Meditation may involve visualization techniques, chanting mantras, or simply focusing on one's breathing or a koan..$^{30}$

About Christian contemplation, Ingram states, "The goal of Christian contemplative practices of centering prayer and lectio divina ('divine reading') is experiential confirmation of the truth of Christian teachings 
about God as incarnated in the life, death, and resurrection of the historical Jesus." ${ }^{11}$ What questions might arise from Buddhist-Christian Interior Dialogue as Ingram identifies these practices?

A Buddhist chaplain might ask a Christian chaplain, "How does your contemplative practice help you connect with Jesus?" And, "Did your connection with Jesus help you connect with , the transgender patient?" The Christian chaplain might ask the Buddhist chaplain, "Do you ever use 's (the transgender patient) image as an object of meditation? If so, how does that impact how you relate to ?" Authentic questions will arise as appropriate and the dialogue can proceed from the contemplation, meditation, and development of intrapsychic material.

Somewhere between Buddhist-Christian Conceptual, Socially Engaged, Natural Science, and Interior dialogue is the question of the purpose of the Lord's Prayer, prayed in countless Christian communities and homes throughout the world. It reads,

Our Father who art in heaven,

Hallowed be thy name.

Thy kingdom come.

Thy will be done

on earth as it is in heaven.

Give us this day our daily bread, and forgive us our trespasses, as we forgive those who trespass against us, and lead us not into temptation, but deliver us from evil.

For thine is the kingdom, and the power, and the glory, for ever and ever Amen.

For Buddhists like Nhat Hanh (those who believe the heavenly realm is here but unactualized) in dialogue with Christians refusing to provide appropriate spiritual care for transgender patients, I would begin the dialogue by asking, "What does it mean to you when you pray 'Thy kingdom come, thy will be done, on earth as it is in heaven?" With this question alone, a dialogue on the concepts of "thy," "kingdom," and "heaven" can begin. The word "earth" can lead into a Natural Science dialogue. "Will be done" can ignite a dialogue on social engagement. The 
entire prayer itself can lead to a dialogue that is Interior focused. Christians might ask Buddhists, who believe heaven is on earth in the here and now, "What does it feel like? How do you achieve it? What are the hindrances to living a heavenly life now?"

In addition to Ingram's four processes of interreligious dialogue, including Conceptual, Natural Science, Socially Engaged, and Interior, I have added Law, Government, Psychology, and Religious Anthropology. Christians and Buddhists engaged in interreligious dialogue related to the spiritual care of transgender people must also include topics like law and politics in their conversations. For example, regarding the Restoration of Religious Freedom Act (a subject I discuss in Chap. 4) and other laws promulgated for protecting one's religious freedom to discriminate against others, interreligious dialogue partners could discuss the following questions:

1. How do you determine which US citizens should have the religious freedom to discriminate against others?

2. Are you willing to advocate for overturning the equal protection clause of the Fourteenth Amendment?

3. Are you willing to support RFRA at the risk of impoverishing other citizens?

4. If yes, what is your moral obligation to support those you've helped impoverish?

5. What if pure Christianity is determined, in part, on the basis of whether one observes the Sabbath? In America as it is today, nearly $100,000,000$ or 29 percent of Americans work on the weekends. Does working on the weekend make one an impure Christian worthy of being discriminated against in the workplace by Sabbathobserving Christians?

6. Should Christians be discriminated against by non-Christians?

7. What are the actual religious practices in your religion that dictate your negative behavior toward transgender citizens?

8. How do you feel about your own sexuality?

9. Keeping Judith Butler in mind, "What are your thoughts on cohabitation?"

According to Winnifred Fallers Sullivan, the chaplain's "religion" or "ministry of presence" is universalist, as in, non-proselytizing. But she asks if this religion of presence is "a conformist kind of religion that accepts law 
enforcement's categorization of people as law abiders or lawbreakers, or is it a place of resistance to the modern state, sometimes standing with the scofflaw and his Journey?" 32 It could be that the "religion of presence" is conformist for some, as it has been for some CPE interns and residents who need to put their beliefs and practices aside for several weeks or months as they learn the art of spiritual care. For others, the "religion of presence" may be resistance to the modern state and ancient religion. There is at least one more alternative that presence isn't akin to a new kind of religion, but a posture toward the promotion of a civilized society. As it relates to the chaplain's role as a government actor, and as a force for modern state resistance, Buddhist and Christian dialogue partners Nhat Hanh and Catholic priest Daniel Berrigan provide rich examples.

Nhat Hanh and Daniel Berrigan, a Catholic priest, engaged in Interreligious Dialogue on Government in this way:

Berrigan: [engaging in Buddhist-Christian Socially Engaged Dialogue on Government] One has to keep reminding oneself and other people that an exalted contempt for human life lies in the basis of democracy and that one had better think of the unprotected and innocent, and be prepared for bad news when the leaders meet. ${ }^{33}$

Nhat Hanh: These governments always say that for their actions to be effective they must be kept secret. Somewhere their democratic claim goes wrong; it is no longer clear what kind of democracy they dream of. ${ }^{34}$

Berrigan: I think one important aspect of this is the supposition that a well-informed public can change things. "Well-informed" usually involves one or another cliché about the role of the media-the press and television... Because the people can very easily, as in the United States, be lulled into a belief in "free press" and "free television." 35

Nhat Hanh: So even when there is "free press," a great problem remains. Berrigan: [engaging in Buddhist-Christian Interior Dialogue] So, the question of selecting, meditating, having some interior life of one's own in the midst of all this, becomes quite important. Especially in such times as these, to have a modest estimation of one's own life-that's a very important form of sanity. ${ }^{36}$ 
Nhat Hanh: In a situation where fear and hatred and anger prevail, we must still work effectively and we need, very much, the clarity to see, to be serene, to be ourselves first. And then, being so, we can reassure a few friends who are closer to us and can begin to think of something to do. ${ }^{37}$

Berrigan: [This is not engaging the Natural Sciences, but Psychology and arguably touching on Conceptual Dialogue regarding the nature of idolatry] I think fear does two amazing things; maybe they are just aspects of one thing. First, it creates the impression that a person is facing a god, usually a god of war or god of violence; fear makes the adversary look superhuman. Secondly, it creates a new psyche in one's self-a very disrupted, distracted, terrorized person, the opposite of a stable, self-aware person. Two aspects, one fear. If one's soul is so enslaved as to bow to the god, one is already destroyed. ${ }^{38}$

Berrigan and Nhat Hanh engaged in Interreligious Dialogue on Government. They talked about the risks of priests (arguably any religious or spiritual leader) becoming elected officials because of the risks of losing their moral compass and pastoral authority because of the compromises they must make to keep their political jobs as they return favors for votes. Chaplains, even as "secular priests" who work in governmental facilities, such as governmentally funded health care institutions, face similar risks of moral injuries when they do not engage in Interreligious Dialogue about Government and their roles as government agents. One way chaplains can avoid losing their moral compass and maintain their pastoral authority is by voicing their opinions in the public sphere about politicians promulgating religious freedom laws to discriminate against minority populations.

In a political era where hospitals (and other health care organizations) have become ground zero for the religious freedom to discriminate against transgender people, should health care employees, through compassion, become part of a political resistance to discriminating against patients in their care? Berrigan and Nhat Hanh, in their Socially Engaged Dialogue, did not discuss hospital contexts or trans people, but discussed the role of chaplains in the prison (governmental institutions) context, and they came to an agreement that prison chaplains should not have the power to 
imprison others while also attempting to provide them spiritual care. Berrigan said:

The problem of how you minister to prisoners remains. It's not solved by saying that you come and go with a bunch of keys. A way must be found to prevent chaplains from taking the salary of the state and standing in the same relationship to prisoners as the guards. Such a chaplain is looking for the same benefits [my emphasis]; he goes up the ladder the way the guards do in salary and in rank, and he retires with a pension, just as they do. This can't help but affect his relationship to the prisoners. In fact, Philip [Daniel's brother] and I have never met a prison chaplain whom we could respect. Not one. ${ }^{39}$

Chaplains, especially cisgender chaplains in health care contexts caring for transgender patients, can ask ourselves similar questions about our cisgender privileges vis-à-vis the health care institutions we are admitted. Why does being cisgender permit us to be cared for? We can ask ourselves in what way or ways do we partner with institutions to diminish the trans patients we serve and ask ourselves if we are doling out "cheap grace" to those patients rather than spiritual care of little transformative value? In other words, have cisgender chaplains become complicit with health care systems of trans oppression if we are not resisting discriminatory policies and laws?

In addition to chaplains in the prison context, Nhat Hanh and Berrigan talk about communities of resistance.

Berrigan: I think the word resistance [my emphasis] became very important around 1967 in the States. People were saying that it was necessary to take a step beyond protest. We could no longer look upon our style of life as merely being an occasion for this or that action. People had to begin thinking much more seriously and deeply about a long-term struggle in which they would stand up more visibly and perhaps with more risk. ... One person refusing induction or going on trial or leaving the university would have no impact. Now there must be a community behind him. ${ }^{40}$

Nhat Hanh: I think that's a very meaningful term. And resistance [my emphasis], at root, I think, must mean more than resistance against war. It is a resistance against all kinds of things that are like war. Because living in modern society, one feels that 
he cannot easily retain integrity, wholeness. One is robbed permanently of humanness, the capacity of being oneself. ... So perhaps, first of all, resistance means you lose yourself. So perhaps, first of all, resistance means opposition to being invaded, occupied, assaulted, and destroyed by the system. The purpose of resistance, here, is to seek the healing of yourself in order to be able to see clearly. ${ }^{41}$

Buddhist and Christian chaplains, through Interreligious Dialogue on Government, can learn from each other about their religious identities and obligations to resist oppression as they provide spiritual care to transgender patients in government-funded health care institutions. Based on my research, chaplains, pastoral counselors, and chaplain educators are not collectively resisting policies and laws as religious and spiritual professionals, that promote hatred and neglect of trans people.

Throughout Nhat Hanh's writings, he reflects a conceptual gender fluidity as it relates to transcending bodily forms in the mystical Avatamsaka world. This mystical world, for Nhat Hahn, is God/Holy Spirit itself, expressed in material form in our unrealized consciousness.

In the phenomenal world, we see that there is birth and death. There is coming and going, being and non-being. But in nirvana, which is the ground of being equivalent to God, there is no birth, no death, no coming, no going, no being, no non-being. All these concepts must be transcended. ${ }^{42}$

In nirvana, the dualistic "concepts" of male or female and the "concept" transgender are transcended. It is likely Paul, Jesus's apostle, would have agreed. In The Letter of Paul to the Galatians, he says,

For you are all sons of God through faith in Christ Jesus. For as many of you as were baptized into Christ have put on Christ. There is neither Jew nor Greek, there is neither slave nor free, there is neither male nor female; for you are all one in Christ Jesus. And if you are Christ's then you are Abraham's seed, and heirs according to the promise. ${ }^{43}$

In Paul's letter to Colossians, he says,

But now you yourselves are to put off all these: anger, wrath, malice, blasphemy, filthy language out of your mouth. Do not lie to one another, since you have put off the old man with his deeds, and have put on the new man 
who is renewed in knowledge according to the image of Him who created him, where there is neither Greek nor Jew, circumcised nor uncircumcised, barbarian, Scythian, slave nor free, but Christ is all and in all. ${ }^{44}$

Nhat Hanh and Paul, like the Buddha and Jesus, are mystical kinfolk of non-dualistic, unifying consciousness that fades away, lessens in importance, loses its power to separate and discriminate, loses its hierarchal meanings, yet brings spirit-world beings together as one. Christian and Buddhist chaplains in dialogue about caring for transgender patients can expand the field of compassionate care by engaging in dialogue about their respective unifying spiritual practices that promote nondiscrimination and support one another in those practices while staying within their religious homes, radically co-inhabiting the clinical space of the pluralistic hospital setting. A true cohabitation of constructive interreligious dialogue that incorporates wisdom, compassion, constitutional vigilance, advocacy, activism, care, and analysis will likely shock a health care system out of fear of, hatred toward, ignorance about, and neglect of caring for transgender patients into a system striving to be hospitable toward all.

Recalling the lawyer who asked Jesus "Who is my neighbor?" it is important to know that the government has a compelling interest in helping its citizens prevent disease (Centers for Disease Control), rehabilitate veterans of war (Veteran's Administration and Hospitals), be healthy (governmental hospitals), and reduce medical costs (Medicaid and Medicare). These compelling governmental interests can be balanced with protecting religious freedom in responsible ways, and chaplains are perfectly positioned to lead the way in demonstrating how these governmental interests may be balanced.

\section{Notes}

1. Winnifred Fallers Sullivan, A Ministry of Presence: Chaplaincy, Spiritual Care, and the Law (Chicago: The University of Chicago Press, 2014), 64.

2. Luke 10:25-37. Unless otherwise noted, all scriptural passages are from the Thompson Chain-Reference Study Bible, New King James Version, compiled and edited by Frank Charles Thompson, published by B.B. Kirkbridge Bible Co., Inc., Indianapolis, IN.

3. Trump Rolls Back Transgender Bathroom Guidelines For Schools. http:// fortune.com $/ 2017 / 02 / 22 /$ trump-lgbt-transgender-bathroomguidelines/ (Accessed September 12, 2018). 
4. President Donald J. Trump Proclaims January 16, 2018, as Religious Freedom Day. https://www.whitehouse.gov/presidential-actions/ president-donald-j-trump-proclaims-january-16-2018-religious-freedomday/ (Accessed September 3, 2018).

5. "This Is Not America," from The Falcon and the Snowman soundtrack, written by Bowie, Pat Metheny, and Lyle Mays. https://en.wikipedia. org/wiki/This_Is_Not_America (1985) (Accessed September 21, 2018).

6. The Discrimination Administration, https://transequality.org/the-discrimination-administration (Accessed September 12, 2018).

7. Erica L. Green, Katie Benner and Robert Pear, 'Transgender' Could be Defined Out of Existence Under Trump Administration, https://www. nytimes.com/2018/10/21/us/politics/transgender-trumpadministration-sex-definition.html (Accessed January 9, 2019).

8. Lawarence Hurley, "U.S. court rules for Trump on transgender military limits," https://www.reuters.com/article/us-usa-court-transgender/ us - court-rules-for-trump-on-transgender-military-limitsidUSKCNIOY1BI (Accessed January 9, 2019).

9. https://www.etymonline.com/word/hospital (accessed August $27,2018)$.

10. Sullivan, 86 .

11. Winnifred Fallers Sullivan, A Ministry of Presence: Chaplaincy, Spiritual Care, and the Law (Chicago: The University of Chicago Press, 2014), 3.

12. Ibid., 38. Though Sullivan is quoting from Veteran Affairs documents, it is the case in many hospitals and hospices that chaplains are part of the health care team that includes social workers, nurses, doctors, and others.

13. Ibid., 50.

14. Finnegan, Joanne, “As complaints trickle in, protecting workers' religious rights could cost health industry upward of $\$ 300 \mathrm{M}$ in First Year, FierceHealth, https://www.fiercehealthcare.com/practices/protectingworkers-religious-rights-cost-healthcare-300m-donald-trump-hhs-rogerseverino, February 6, 2018, (Accessed January 12, 2019).

15. Ibid., 17.

16. Minority Quotes https://www.brainyquote.com/topics/minority (Accessed September 12, 2018).

17. Mendieta and Vanantwerpen, eds., The Power of Religion in the Public Sphere, New York, Columbia Press, 2011, 118.

18. Ibid., 76.

19. Nhat Hanh, Living Buddha, Living Christ, Riverhead Books, 1995, $2007,196$.

20. Nhat Hanh, Living Buddha, Living Christ, Riverhead Books, 1995, 2007, 9 . 
21. American Psychiatric Association, Desk Reference to the Diagnostic Criteria from DSM-5, American Psychiatric, Publishing, Washington, DC (2013), 327.

22. Ingram, 29.

23. Nhat Hanh, Going Home: Jesus and Buddha As Brothers, Riverhead Books, $1999,82$.

24. Liam Muggleton Robins, CPE educator, personal communication, February 17, 2019.

25. Paul O. Ingram, The Process of Buddhist-Christian Dialogue, 2009, 54.

26. Ibid., 66.

27. "What is Gender Dsyphoria" https://www.psychiatry.org/patients-families/gender-dysphoria/what-is-gender-dysphoria (Accessed October 29, 2018).

28. Ibid., 84 .

29. Nhat Hanh, Living Buddha, Living Christ, Riverhead Books, 1995, 2007, 179-180.

30. Ibid., 112 .

31. Ibid.

32. Sullivan, xvi.

33. Thich Nhat Hanh and Daniel Berrigan, The Raft is Not the Shore: Conversations Toward a Buddhist-Christian Awareness, Maryknoll, New York, Orbis, 2001, 73.

34. Ibid.

35. Ibid., 74 .

36. Ibid., 75 .

37. Ibid., 79.

38. Ibid., 80 .

39. Ibid., 55-57.

40. Ibid., 128 .

41. Ibid., 129.

42. Nhat Hanh, Going Home: Buddha and Jesus As Brothers (1997), 10.

43. Galatians 3:26-29, The Thompson Chain-Reference Study Bible, B.B. Kirkbridge Bible Co., Inc. Indianapolis, IN, 1997, 1512.

44. Colossians 3:8-11, The Thompson Chain-Reference Study Bible, B.B. Kirkbridge Bible Co., Inc. Indianapolis, IN, 1997, 1530. 